\title{
Physiological and Infectious Characters of Potato virus $Y$-Egyptian isolate
}

\author{
Seham Abdel-Shafi", Mohamed F. Ghaly, Khalid El-dougdoug* and Mohamed \\ Taha \\ Department of Botany \& Microbiology, Faculty of Science, Zagazig University, \\ Zagazig and "Department of Microbiology, Faculty of Agriculture, Ain Shams \\ University, Cairo, Egypt.
}

\begin{abstract}
Dotato VIRUS Y (PVY) is one of the most destructive aphid transmitted pathogen to potato plants worldwide. In Egypt, PVY infection causing about $80 \%$ reduction the global yield of potato. The objective of this study was to characterize Potato virus Y (PVY-EG) infecting potato plants, based on biological, serological and molecular properties. Naturally infected potato plants by PVY gave positive reaction with PVY-polyclonal antibodies using DAS-ELISA for virus identification. PVY has a higher stability at $45 \mathrm{~h}$ (Longevity), $66^{\circ} \mathrm{C}$ at 10 $\min$ (TIP) at $10^{-6}$ (DEP), revealing presence of cytoplasmic and crystalline inclusion bodies of the epidermal strips from infected Datura metel (diagnostic host) leaves at 12 days post PVY inoculation. The PVY has UV-spectra at $\lambda 235$ and at $\lambda 257 \mathrm{~nm}$. PVY yield was $1.25 / 100 \mathrm{~g}$ leaf tissues and 260/280 more than 1 (it was 1.6). The viral particles were rod flexible (helical symmetry) of $11 \times 570 \mathrm{~nm}$, with obvious immunogenicity that represented by 1:1024 titer of antibodies. The cDNA fragment of CP gene was $610 \mathrm{bp}$. Sequence analysis revealed that PVY isolate showed $93-99 \%$ similarity with other worldwide PVY isolates.
\end{abstract}

Keywords: PVY, Potato, Potyvirus, ELISA, RT-PCR.

\section{Introduction}

The potato (Solanum tuberosum L.) is an important economic crop, however, its infection with potato viruses usually causing severe economic damage affecting both seed quality and trade. Potato virus $Y$ (PVY) is one of the most important aphid transmitted viral pathogen of potato worldwide. It can affect the production of certified seed and also crops grown for processing or fresh market (Rykbost et al., 1999). PVY is a member of the genus Potyvirus (Family Potyviridae), the largest group of plant viruses that encompasses 111 recognized and 86 tentative species infecting more than 30 plant families (Fauquet et al., 2005). It has been revealed that different strains of PVY are closely associated with different degrees of pathogenicity where the most important and common are known to be recombinant (Visser et al., 2012). Primary symptoms of PVY are necrosis or yellowing of leaflets, leaf dropping or sometimes premature death. $\mathrm{PVY}^{\mathrm{O}}$ (common strain) gave mild mosaic, mottle, bronzing and rugosity can arise from mixed infection with PVA, PVX and PVS (Eraky et al., 2014).
In Egypt, PVY was isolated from different crops such as potato, tomato, gladiolus and pepper (Ahmad, 2005 and Al-Nagar, 2007). Also, Mahfouz et al. (2004) isolated three isolates of PVY, four isolates of PVX and three isolates of PVS from naturally infected potato plants cvs. Nicola and Diamont at different farms in Egypt.

The most important vectors of potato virus $\mathrm{Y}$ and establishment their relative efficiencies of transmission was recorded by Alyokhin et al. (2002). Myzus persicae, Phoredon humuli and Aphis spp. accounted for 90\%, meanwhile, Bracycaudus helichrysi represents alone $52 \%$ of transmission, respectively.

Stability of Potato virus $Y$ was determined in sap of infected potato plants, the thermal inactivation point (TIP) for $\mathrm{PVY}^{\mathrm{N}}$ was $55-60^{\circ} \mathrm{C}$, while, its dilution end point (DEP) was $10^{-3}$ in sap extracted from potato leaves showing mild symptoms (Hossain \& Ali, 1992). DEP $10^{-2}-10^{-3}$, TIP 60$65^{\circ} \mathrm{C}$, LIV 5-15 days, one type of an antigen with MW c.34 KDa, serological activity and symptoms caused on tobacco cv. Samsun. The TIP of Potato virus $Y$ was ranged from $55-60^{\circ} \mathrm{C}$, DEP was $10^{-4}$ 
and LIV at $20^{\circ} \mathrm{C}$ was within $24 \mathrm{~h}$ in sap extracted from infected Wedelia trilobata (Linno) (Sheikh et al., 2012).

The virions of the viruses belonging to the Potyvirus genus are rod-shaped flexuous filaments $680-900 \mathrm{~nm}$ long and $11-13 \mathrm{~nm}$ wide. The virions have a monopartite, positive-sense single-stranded RNA, that is about $9.7 \mathrm{~kb}$. Approximately 2000 subunits of a single coat protein are organized around the viral genomic RNA in a helical arrangement (Shukla et al. 1994).

Frequency and severity of PVY, methods of viral detection are needed. Therefore, the objective of this work was aimed to detect and isolate PVY infecting potato plants in Egypt. As well as its biological, serological and molecular characterization.

\section{Materials and Methods}

Collection of leaves samples and detection of potato viruses

The PVY was isolated from naturally mixed infection potato plants (50 samples) cultivated in different locations in El-Sharkia, Egypt, during spring, 2011. Different distinct viral systemic symptoms on plant leaves were recorded. The potato viruses (PVY, PVX, PLRV) were detected in naturally infected potato plants using polyclonal antibodies kit (Sanofi, Sante, Animal, Paris, France) by double antibody sandwich enzyme linked immunosorbent assay (DAS-ELISA) (Clark \& Adams, 1977).

\section{Isolation of PVY}

The infected potato plants gave positive results with PVY specific antibodies were used for PVY isolation and identification. Differential host, Datura metel was mechanically inoculated with infectious sap of infected potato for PVY isolation. Indicator plant, Chenopodiumam amaranticolor L., was inoculated with virus isolate for single lesion isolation and grown under a greenhouse conditions. The five local lesions morphological identical were separated and crushed in $0.1 \mathrm{M}$ phosphate buffer ( $\mathrm{pH}$ 7)between two slide glass. The crude extract was mechanically inoculated on Nicotiana tabacum cv. white burly for virus propagation. The inoculated plants were kept under greenhouse conditions for symptoms development at $26 \pm 2{ }^{\circ} \mathrm{C}$.

\section{Propagation of PVY-isolate}

The external symptoms were observed and confirmed by DAS-ELISA (Nerway \&
Kassim, 2014). The homologous local lesions were separated and grinded in mortar with (1:1 w/v) $0.1 \mathrm{ml}$ phosphate buffer containing $0.1 \mathrm{M}$ sodium phosphate $\mathrm{pH} 7.5,10 \mathrm{mM} \mathrm{Na}_{2} \mathrm{SO}_{4}$ and $2 \mathrm{mM}$ EDTA. The extracted sap were squeezed and filtered through two layers of cheesecloth. The filtrated crude sap containing viral particles (infectious sap) was ready for inoculation. The PVY-infectious sap was mechanically inoculated on Nicotiana tabacum cv. White Burley for propagation of PVY-isolate (15 plants). The inoculated plants were maintained under insectproof cages in greenhouse conditions at $26 \pm 2^{\circ} \mathrm{C}$ for 14 to 21 days before use for either biological testing or purification of the virus.

\section{Determination of host range}

Twenty-three plant species and cultivars, belonging to six families (Amaranthaceae, Chenopodiaceae, Compositae, Cucurbitaceae, Fabaceae and Solanaceae) were tested after (Mahfouz, 2003). The tested plants were mechanically inoculated by infectious sap of the isolated PVY isolate. The inoculated plants were kept under greenhouse conditions for symptoms development. The external symptoms were observed and confirmed by DAS-ELISA using polyclonal antibodies specific for Potyvirus group.

Mode of transmission:

\section{Mechanical sap transmission}

Healthy potato cvs.Diamont and spounta (30 days) and differential hosts, Ch. amarnticolor L., Capsicum annuum cv. California wonder, Datura. metel L., Lycopersicon esculantum L. cv. Castle rock, N. tabacum cv. Samsun NN. (Mahfouz, 2003) were mechanically inoculated with infectious sap of PVY-inoculum isolate. The inoculated hosts were kept under insect-proof cages in a greenhouse conditions, at $26 \pm 2^{\circ} \mathrm{C}$ for 14 to 21 days, till the developed external symptoms and confirmed with DAS-ELISA.

\section{Aphid transmission}

It was carried out by using colonies nonviruliferous aphids Myzus persicae Sulz. Aphids were collected from the potato field and identified by Plant Protection Dept. Fac. Agri., Ain Shams Univ. The collected aphids were reared on cabbage seedlings under insect-proof cages. Filial generations, nymphal and adult stages were used in non-persistent manner transmission.

Aphids were fasted 15 min before transferring to infected potato $\mathrm{cv}$. Diamont plants. The aphids (10 insects/plant) were left to feed on the infected 
leaves with PVY-isolate for 5, 10, 20 and $30 \mathrm{~min}$. and then transferred to 3 healthy potato plants cv. spounta. All the insects were allowed to feed for one hour, and then killed by spraying malathion at conc. $0.2 \%$. Inoculated plants were kept under insect-proof cages in a greenhouse conditions under observation till 25 days post-inoculation and observed the developed external symptoms. The inoculated plants were tested for PVY infection using Ch. amaranticolor L. and confirmed by DAS-ELISA (Nerway \& Kassim, 2014).

\section{Graft transmission}

Bud eye from potato tubers of the infected cv. spounta were grafted on healthy ones. Grafted eye tubers and scions were tied together with paraffin wax and cultivated on pots under insect proof in greenhouse conditions. One to two months after grafting all plants were serologically tested using ELISA and investigated to PVY distinct symptoms.

\section{In vitro stability of $P V Y$-isolate}

To study the in vitro stability of PVY-isolate (TIP, DEP and LIV), infectious crude sap of PVYinfected N. tabacum cv. White burly leaves were extracted 4 weeks post-inoculation. Leaves of Ch. amaranticolor L., plants were mechanically inoculated with PVY-infected treated sap and kept under a greenhouse conditions (Walkey, 1985).

\section{Light microscope examination}

For crystalline and amorphous viral inclusions in epidermal strips of the leaves systemically PVY-infected N. tabacum cv. Samsun NN were examined as described by Jordan \& Baker (1955).

\section{Purification of PVY isolate}

Virus purification was done according to Rupar et al. (2013). The purity of PVY isolate was evaluated, biologically, spectrophotometrically and electron microscopy.

\section{Infectivity assay}

Infectivity assay of PVY purified isolate was done on Ch. amaranticolor leaves by rubbing the purified virus inoculums. Ten fold dilutions up to $10^{-8}$ was applied. Five replicates for each diluted was carried out for appearance of chlorotic local lesions.

\section{Ultraviolet absorption spectrum}

Purified virus was scanned in a Shimadzu UV 1201 spectrophotometer UV absorption at UV range from 220 to $300 \mathrm{~nm}$ (intervals $5 \mathrm{~nm}$ ) maximum, minimum, A260; 280;260/280 and $280 / 260$ values were calculated.The virus yield was calculated according to Noordam (1973) as follows:

Virus yield $=\frac{\text { O.D.(260) X Dilution factor }}{}$ whereas:

O.D. $=$ optical density at $260 \mathrm{~nm}$

E.C. =extinction coefficient $2.8\left(\mathrm{mg} / \mathrm{ml}^{-1} \mathrm{~cm}^{-1}\right)$

Transmission electron microscope

Small drops of purified virus were placed on carbon-coated grids for one minute and dried. Virus particles existed on grids were stained using $2 \%$ uranyl acetate and dried then examined using electron microscope in National Research Centre, Egypt (Sharma et al., 2013).

\section{Molecular characters}

Reverse transcription- polymerase chain reaction (RT-PCR)

Total RNAs were prepared from infected N. tabacum cv. white burly leaves with PVYisolate according to the instruction manual of High Pure RNA tissue kit (Version 1, 2000) from Roche diagnostics $\mathrm{GmbH}$, Germany. The eluted RNA was stored at $-80^{\circ} \mathrm{C}$ for later analysis. Agarose electrophoresis and spectrophotometry were performed (Mahfouz, 2003). Two oligonucleotide primers were used to generate cDNA and amplify the $P V Y-C P$ gene. The $3{ }^{\prime}$-end primer sequence $5{ }^{\circ}$ - ggatccacatgt $\mathrm{t}(\mathrm{c} / \mathrm{g}) \mathrm{tt}(\mathrm{c} / \mathrm{g})$ act ccaag $(\mathrm{t} / \mathrm{c})$ ag- 3 , was based on the complete nucleotide sequences of the previously published sequence of the PVYN and partially degenerate. The $5{ }^{\circ}$-end primer sequence $5^{`}$ - ggatccatg $\mathrm{g}(\mathrm{g} / \mathrm{c})$ aaatgacacaat (t/c) gat gca -'3 (Sudarsono et al. 1993). The oligo-nucleotide primers were synthesized in Thermo Hybaid GmbH, Germany. Viral cDNA was synthesized and amplified as procedure according to Hadidi et al. (1993). One $\mu \mathrm{g}$ of RNA, $3 \mathrm{ml}$ of the primers, $6 \mu \mathrm{l}$ of $5 \mathrm{X}$ first strand cDNA buffer (250 mMTris-HCl, pH 8.3; $500 \mathrm{mMKCl}$; $\left.15 \mathrm{mM} \mathrm{MgCl}_{2}\right), 3 \mu \mathrm{l}$ of 0.1 Mdithiothreitol (DTT), were added to a final volume of $30 \mu \mathrm{l}$ by deionized water. The mixture was heated for $5 \mathrm{~min}$ at $95^{\circ} \mathrm{C}$, and directly chilled in ice for $2 \mathrm{~min}$, then incubated at room temperature for $1 \mathrm{~h}$ to allow primer annealing to the RNA template. Twenty $\mu 1$ of reaction solution $(4 \mu \mathrm{l}$ of $5 \mathrm{X}$ first strand cDNA buffer, $5 \mu \mathrm{l}$ of $0.3 \mathrm{M} \beta$-mercaptoethanol, $2.5 \mu \mathrm{l}$ of $10 \mathrm{mM}$ each deoxynucleotide triphosphate (dNTPs), $1 \mu \mathrm{l}$ of RNasin (40 units/ $\mu \mathrm{l}), 2 \mu \mathrm{l}$ of 0.1 Mdithiothreitol (DTT), $4.5 \mu \mathrm{l}$ deionized water, and $1 \mu \mathrm{l}(10.000$ units/ $\mu \mathrm{l})$ of Moloney Murine Leukamia Virus reverse transcriptase (MMLVRT) (Promega, Co) were mixed with annealing 
reaction mixture, incubated for $1 \mathrm{~h}$ at $42^{\circ} \mathrm{C}$. Amplification was performed in thin walled PCR tubes. Each tube containing the following reaction mixture: $5 \mu$ of 10xPCR buffer $(10 \mathrm{mM}$ Tris- $\mathrm{HCl}$, $\mathrm{pH} 8.3 ; 50 \mathrm{mM} \mathrm{KCl}$ and $0.001 \%$ gelatin), $3 \mu \mathrm{l}$ of $25 \mathrm{mM} \mathrm{MgCl}_{2}, 1 \mu \mathrm{l}$ of $10 \mathrm{mM}$ dNTPs, $5 \mu \mathrm{l}$ of 10 pmol each downstream and upstream primer for PVY-CP, 2.5 units of Taq DNA polymerase, and sterile water to a volume of $50 \mu \mathrm{l}$, and ' hot start ' at $94{ }^{\circ} \mathrm{C}$ for $5 \mathrm{~min}$ in a programmable thermocycler. Five $\mu$ of the cDNA mixture was added to the PCR reaction and amplified with the following cycling parameters: The amplification proceeded through 35 cycles of denaturation at $94^{\circ} \mathrm{C}$ for $1 \mathrm{~min}$ followed by annealing at $57^{\circ} \mathrm{C}$ for $1 \mathrm{~min}$. and primer extension at $72^{\circ} \mathrm{C}$ for $2 \mathrm{~min}$, with a final extension step of $72^{\circ} \mathrm{C}$ for $7 \mathrm{~min}$. PCR amplification was performed in an Thermoblock cycler PCR (Biometra) (Mahfouz, 2003). The amplified DNA products of the $C P$ gene 1 was visualized on UV transilluminator $(\lambda 254 \mathrm{~nm})$ and photographed by Gel Documentation System (GELDOC 2000, BioRad, USA). pGEM DNA marker (Promega) was used to determine the size of RT- PCR amplified cDNA products.

Sequencing and computer analysis
Partial nucleotide sequencing of the PCR product of coat protein gene for PVY isolate, which purified from the low melting point agarose gel using Q1A quick gel extracted kit cat. No. 28702. The nucleotide sequencing was carried out at the Gene Analysis Unit, Egyptian Company for Blood Transfusion Services (VACSERA) by ABI PRISM Sequencer model 310 version 3.4. The sequence data, multiple alignment, phylogenetic relationship and antigenic index were translated and analyzed by DNAMAN program (Wisconsin, Madison, USA).

\section{Results}

The current study was undertaken to PVY isolation, identification and molecular characterization.

\section{Field inspection}

Potato viruses diseases were diagnosed in naturally infected potato plant, (Solanum tuberosum cv. spounta) grown under open field conditions. The naturally infected potato leaves showed systemic viral symptoms mild and severe mosaic, rugosity, vein necrosis, leaf narrow, leaf roll, chlorosis, epinasty, yellowing, shortening of internodes, mottling and plant stunting (Table 1).

TABLE 1. Frequency of potato viruses infected potato plants grown under field conditions.

\begin{tabular}{lcc}
\hline Potato viruses & No. of infected plants & Frequency \% \\
\hline PVX & 4 & 16 \\
PVY & 8 & 32 \\
PLRV & 2 & 8 \\
PVX+PVY & 6 & 24 \\
PVX+PLRV & 2 & 8 \\
PVY+PLRV & 2 & 8 \\
PVX+PVY+PLRV & 1 & 4 \\
Total number of infected plants. & 25 & \\
\hline
\end{tabular}

\section{Potato viruses detection}

Potato viruses PVY, PVX and PLRV were detected in naturally infected potato plants exhibited distinct viral symptoms, i.e. mosaic, necrosis, leaf roll on middle leaves of plants by following the method of DAS-ELISA using specific polyclonal antibody of PVY, PVX and PLRV (Table 2). The obtained results indicated that, the leaf samples of cv. spounta naturally infected with PVY, PVX and PLRV individually and their mixture which gave positive reaction with polyclonal antibodies specific PVY, PVX and PLRV.

\section{PVY isolation}

PVY was isolated biologically on $C h$. amaranticolor. L. from the selected DAS-ELLSA positive potato plants. After 5-10 days from inoculation localchlorotic lesions symptoms with the same morphological characters (small chlorotic lesion without halo) were developed (Fig 1). The typical systemic external symptoms 
of leaf crinkle, mottling, severe mosaic produced till it gives deformation and stunting of plant growth $N$. tabacum cv. white burly after 20 to 30 days from inoculation. These plants were kept under insect proof into greenhouse conditions for virological studies.

TABLE 2. Detection of potato viruses in naturally infected potato plants $\mathrm{cv}$.spounta using DAS-ELISA Techniq UE.

\begin{tabular}{|c|c|c|c|}
\hline \multirow[t]{2}{*}{ Leaf symptoms } & \multicolumn{3}{|c|}{ DAS-ELISA } \\
\hline & PVY & PVX & PLRV \\
\hline $\mathrm{mM}, \mathrm{N}, \mathrm{E}, \mathrm{LN}$ & +0.475 & 0.189 & 0.174 \\
\hline $\mathrm{SM}, \mathrm{N}, \mathrm{LN}$ & +0.572 & +0.421 & 0.125 \\
\hline SM, E, D & 0.175 & +.0521 & 0.151 \\
\hline SM, VN, LN & +0.385 & +.0375 & 0.195 \\
\hline $\mathrm{MO}, \mathrm{LR}, \mathrm{VN}$ & +0.175 & 0.257 & +0485 \\
\hline VN, M, E, D & +0.452 & 0.172 & .0175 \\
\hline $\mathrm{E}, \mathrm{R}, \mathrm{RU}, \mathrm{MO}$ & 0.0225 & +0472 & 0.128 \\
\hline RU, MO, LR & 0.185 & +0.381 & +0.312 \\
\hline $\mathrm{N}, \mathrm{LN}, \mathrm{MO}$ & +0.625 & +0.423 & 0.195 \\
\hline S, LR, D,E & 0.225 & 0.172 & +0.325 \\
\hline $\mathrm{E}, \mathrm{Mo}, \mathrm{N}$ & +0.453 & +0.421 & 0172 \\
\hline $\mathrm{E}, \mathrm{N}, \mathrm{LN}$ & +0.521 & 0.211 & 0.192 \\
\hline $\mathrm{VN}, \mathrm{mM}, \mathrm{Cl}, \mathrm{LR}$ & +0.586 & +0.410 & +0.320 \\
\hline N, E, Ci & +0.520 & 0.212 & 0.172 \\
\hline VN, Y, D & +0.721 & 0.205 & 0.191 \\
\hline E, LR, SI, S & 0.210 & 0.159 & +0.320 \\
\hline $\mathrm{mM}, \mathrm{VN}$ & +0.420 & +0.521 & 0.212 \\
\hline NS & 0.251 & +0.321 & 0.173 \\
\hline E, M, LR & 0.210 & +0.425 & +0.325 \\
\hline SI, SM & 0.125 & +0.310 & 0.192 \\
\hline VN, Ch, D & +0.521 & 0.182 & 0.200 \\
\hline $\mathrm{Y}, \mathrm{VN}, \mathrm{CI}$ & +0.531 & 0.193 & +0.310 \\
\hline $\mathrm{M}, \mathrm{SI}, \mathrm{VN}$ & +0.425 & 0.212 & 0.210 \\
\hline $\mathrm{E}, \mathrm{CI}, \mathrm{N}, \mathrm{M}$ & +0.452 & +0.421 & 0.177 \\
\hline
\end{tabular}

$\mathrm{CI}=$ Curled inward; $\mathrm{LR}=$ Leaf roll; $\mathrm{RU}=$ Rossette linke growth; $\mathrm{Ch}=$ Chlorosis

$\mathrm{mM}=$ Mild mosaic; $\mathrm{SM}=$ Severe mosaic $; \mathrm{E}=$ Epinasty; Mo = Mottling; $\mathrm{S}=$ Stunting

$\mathrm{LN}=$ Leaf narrow; $\mathrm{N}=$ Necrosis; $\mathrm{SI}=$ Shortening of internodes; $\mathrm{M}=$ Mosaic; $\mathrm{Ns}=$ No symptoms

$\mathrm{SNS}=$ Systemic necrotic spots; $\mathrm{VN}=$ Veinal necrosis; $\mathrm{R}=$ Rugosity $\mathrm{Y}=$ Yellowing

$\mathrm{D}=$ deformation; $\quad$-ve control $=0.173 ;+$ ve control $=$ 0.651
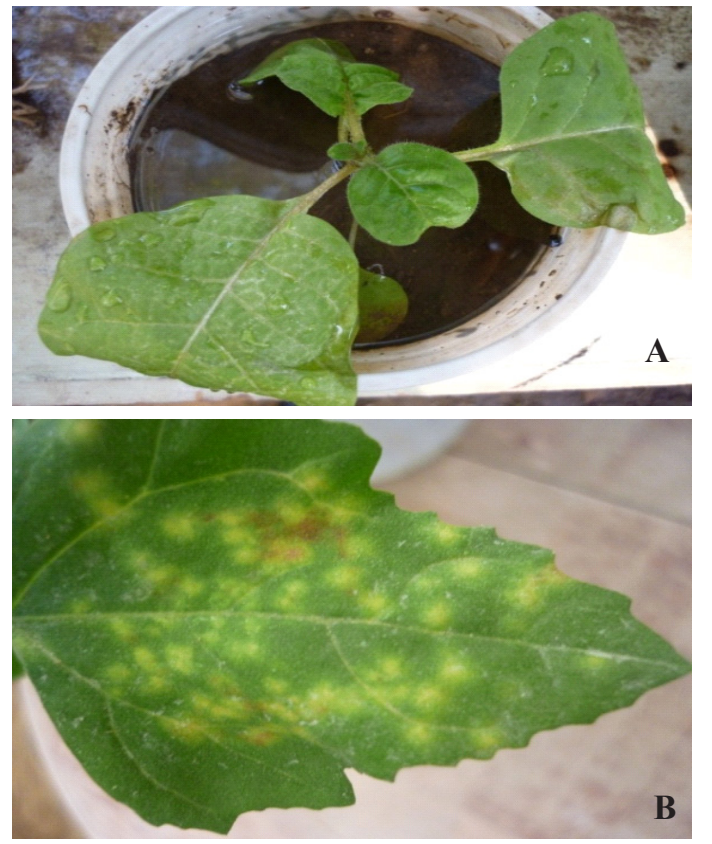

Fig. 1. (A) Ch. amaranticolor plants inoculated with infectious sap of naturally infected potato cv. spounta showing chlorotic local lesion. (B) N. tabacum cv. White Burley inoculated with PVY isolate showing leaf crinkle, mottling, severe mosaic symptoms.

PVY isolate identification

Mode of transmission

PVY isolate was mechanically transmitted from infected potato cv. spounta to healthy potato by $90 \%$ and Datura metel with $75 \%$. The efficiency of aphid transmission was higher than rubbing with sap (85\%) under greenhouse conditions. In addition, it was transmitted with percent $100 \%$ through graft healthy tuber cv. spounta with bud eye from infected tuber. The results were confirmed by DAS-ELISA using specific PVY polyclonal antibodies.

\section{Virus symptomology}

The tested plants, Table 3 showed different susceptibility to the PVY isolate when inoculated by rubbing infectious sap. PVY isolate was reacted with three categories with these plants (Table 3 and Fig. 2). Two species out of twenty-three tested plants were (Ch. amaranticolor and Ch. murale were reacted with local infection which appeared chlorotic local lesions (Fig. 2). Twelve plants belong to five families reacted systemically with PVY isolate. Nine plant species not reacted with PVY isolate. These results were confirmed by DAS-ELISA using polyclonal antibodies specific potyvirus group (Table 3). 
TABLE 3. Reaction between host plants and tested PVY isolate using rubbing sap inoculation and confirmed by DAS -ELISA.

\begin{tabular}{|c|c|c|c|c|}
\hline \multicolumn{2}{|c|}{ Differential host plants } & \multirow[t]{2}{*}{ Symptoms } & \multirow{2}{*}{$\begin{array}{c}\text { Days-post } \\
\text { inoculation (days) }\end{array}$} & \multirow{2}{*}{$\begin{array}{l}\text { DAS- } \\
\text { ELISA }\end{array}$} \\
\hline Plant family & Plant species & & & \\
\hline Amaranthaceae & Gomphorena globosa & $\mathrm{M}, \mathrm{VB}$ & 21 & 0.325 \\
\hline \multirow[t]{3}{*}{ Chenopodiaceae } & Chenopodium amaranticolor & L. Chl & 9 & 0.358 \\
\hline & Ch. quinoe. & NS & - & 0.110 \\
\hline & Ch. mural L. & L.Chl & 10 & 0.243 \\
\hline \multirow[t]{2}{*}{ Compositae } & Zinnia elegans L. & NS & - & 0.120 \\
\hline & Chrysanthemum morifolium & $\mathrm{M}, \mathrm{VB}$ & 22 & 0.312 \\
\hline \multirow[t]{3}{*}{ Cucurbitaceae } & Cucumber sativus cv. Beutalpha & NS & - & 0.130 \\
\hline & Cucurbita pepo cv. Eschandarani & NS & - & 0.175 \\
\hline & Phaseolus vulgaris cv. Pronko & $\mathrm{M}, \mathrm{VB}, \mathrm{CL}$ & 21 & 0.313 \\
\hline \multirow[t]{6}{*}{ Fabaceae } & Vicia faba cv. Giza 3 & NS & - & 0.105 \\
\hline & Vigna unguicuta $\mathrm{L}$. & NS & - & 0.120 \\
\hline & Capsicum annuum cv. Chilli & $\mathrm{VB}, \mathrm{Cr}, \mathrm{CP}$ & 15 & 0.425 \\
\hline & Datura innoxia $\mathrm{L}$. & NS & - & 0.131 \\
\hline & D. metel L. & SM, D, Mo & 17 & 0.521 \\
\hline & D. stramonium & NS & - & 0.140 \\
\hline \multirow[t]{8}{*}{ Solanaceae } & Lycopersicon esculentum cv. Castle rock & $\mathrm{SM}, \mathrm{D}, \mathrm{Cr}, \mathrm{CP}$ & 15 & 0.435 \\
\hline & Nicarchia physaloides L. & SM, D. & 14 & 0.311 \\
\hline & Nicotiana Clevelandii L. & NS & - & 0.115 \\
\hline & N. glutinosa L. & $\mathrm{M}, \mathrm{VN}$ & 17 & 0.345 \\
\hline & N. rustica & M & 19 & 0.437 \\
\hline & N. tabacum Cv. White burly & M & 18 & 0.375 \\
\hline & Petunia hybrid L. & SM, D & 15 & 0.412 \\
\hline & Physdlis floridana $\mathrm{L}$. & M & 12 & 0.425 \\
\hline
\end{tabular}

Negative control $=0.112$ Positive control $=0.527$

$\mathrm{M}=$ Mosaic $\quad$ Lchl $=$ local chlorotic lesion

$\mathrm{VB}=$ Vein banding $\quad$ NS $=$ No symptoms

$\mathrm{CL}=$ Leaf curl $\quad \mathrm{D}=$ Deformation

$\mathrm{Cr}=$ Leaf crinkle $\quad \mathrm{N}=$ Necrosis

$\mathrm{SM}=$ severe mosaic $\quad \mathrm{VN}=$ Veinal necrosis

$\mathrm{CP}=$ Cup shape $\quad$ Mo $=$ Mottling 

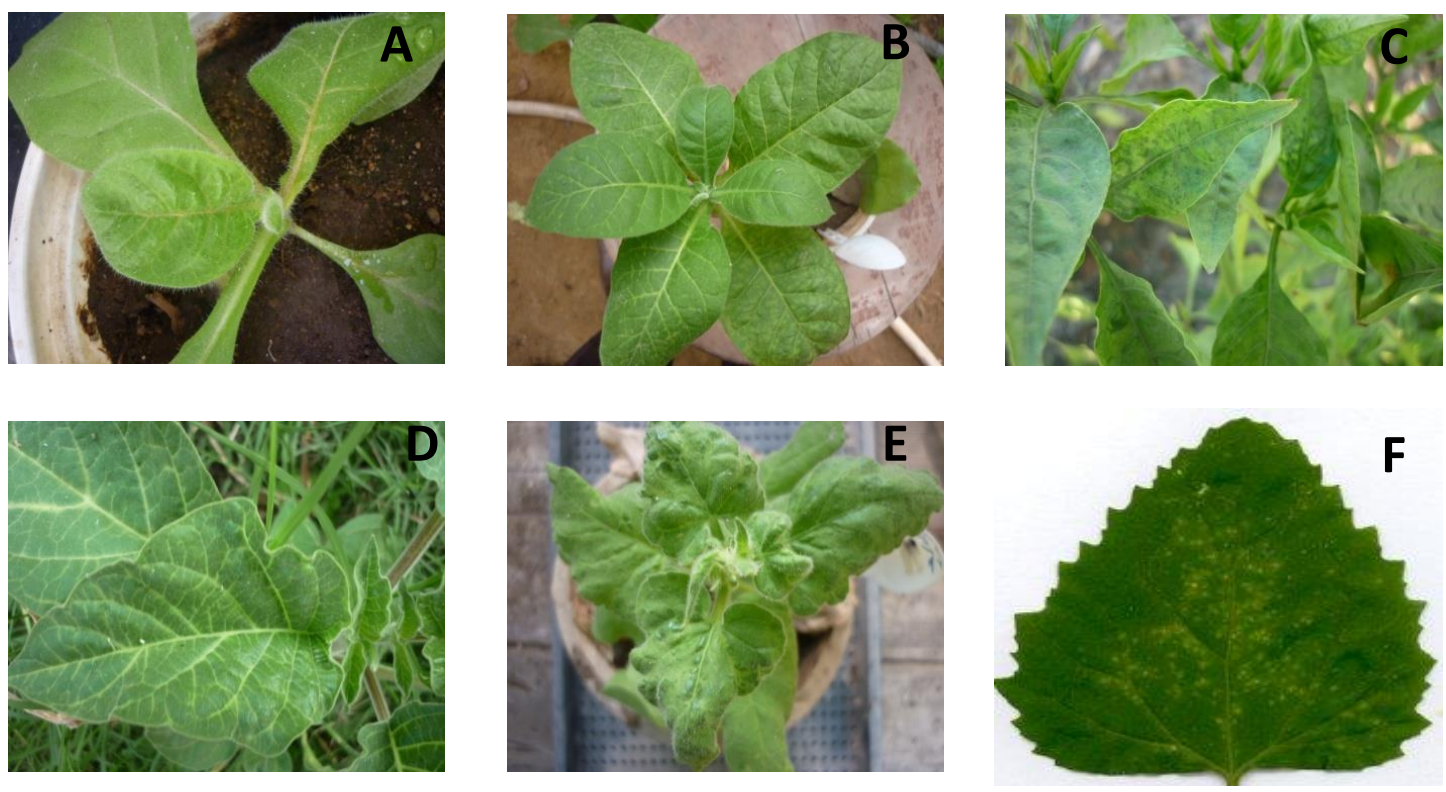

Fig. 2. Host plants inoculated with PVY isolate showing different symptoms.

(A) N. tabacum cv. White Burley; (B) Nicotiana rustica; (C) Pepper; (D) D. metel; (E) N. glutinosa; (F) Ch. amaranticolor.

\section{Inclusion bodies}

The crystalline inclusions are observed in epidermal cells as well as amorphous inclusions stained by bromophenol blue and mercuric chloride (Fig. 3).

\section{PVY isolate stability}

The result of TIP showed that PVY isolate was completely inactivated in crude sap when heated to $66^{\circ} \mathrm{C}$ for $10 \mathrm{~min}$ PVY has DEP at $10^{-6}$ and was completely inactivated when diluted up to $10^{-7}$ at room temperature. The result revealed that, PVY was completely inactivated after $45 \mathrm{~h}$ when kept at room temperature (Table 4).

\section{PVY particles morphology}

Transmission electron microscope examination of partially purified preparation from infected potato leaves negatively stained with uranyl acetate revealed the rod flexible (helical symmetry) particles of PVY with 11 X $570 \mathrm{~nm}$ (Fig. 4).

\section{PVY-CP gene properties \\ RNA yield}

The total RNA extracted from mechanical inoculated N. tabaccum cv. white burly with PVY isolate was evaluated before PCR amplification using spectrophotometer at $260 \mathrm{~nm}$ and running on agarose $(1.5 \%)$. The concentration of total RNA was $3.2 \mathrm{ug}$ per 0.5 gm leaves. The RNA fragment appeared on the agarosegel (total RNA extracted from potato leaves cv. spounta) indicating of success of total RNA extraction with the high density (Fig. 5).

The total RNAs from PVY infected N. tabacum cv. White Burley, potato cv. spounta leaves were reverse transcribed by RT-PCR using the one oligonucleotide downstream primer for PVY-CP gene. On the other hand, no transcription with the healthy one.The viral cDNA was amplified by PCR using primer sets for PVY/CP-gene. The size of the amplified PCR product of PVY/ CP-gene from RNA of infected potato and $N$. tabacuum leaves were estimated by comparing its electrophoretic mobility with those standard DNA ladder (PGEM DNA marker Promega) as shown in Fig. 5. The amplified DNA was in the expected sizes calculated (610 bp). But in case of lane (5) no RT-PCR amplified product was observed with uninfected potato healthy leaves.

\section{Nucleotide sequence analysis}

The partial sequence of the PCR-amplified fragment for the coat protein (CP) gene of PVY isolate was done to determine the relationship with other recommended PVY isolates. Nucleotide was found to be $610 \mathrm{bp}$ from $\mathrm{CP}$ genome sequence (Fig. 5). 


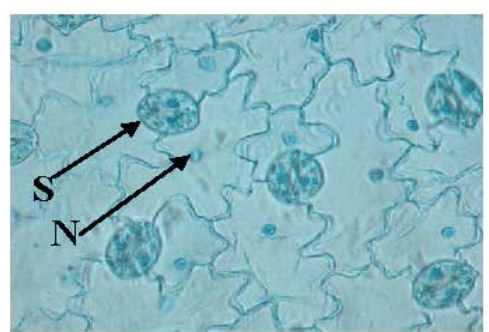

(A) healthy $D$. metel.

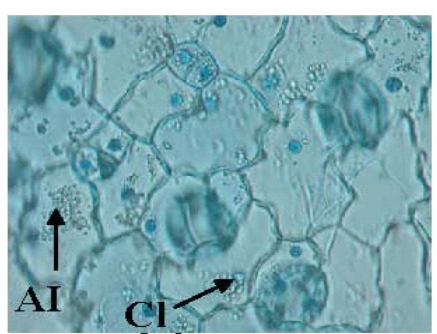

(B) infected Datura metel leaves with PVY.

Fig. 3. Light micrography of epidermal strips and hairs PVY infected Datura metel leaves (17 days post inoculation) showing cytoplasmic inclusion bodies, Magnification $(x-400)$

CI: Crystalline inclusion bodies; AI: Amorphous inclusion bodies; S: Stomata; N: Nucleus.

TABLE 4. Assessment of PVY isolate particles stability in infectious sap at room temperature using local lesion assay.

\begin{tabular}{|c|c|c|c|c|c|c|c|c|}
\hline \multicolumn{3}{|c|}{ TIP } & \multicolumn{3}{|c|}{ DEP } & \multicolumn{3}{|c|}{ LIV } \\
\hline Temp.C & $\begin{array}{l}\text { No of } \\
\text { L.L.** }\end{array}$ & Infectivity*** & Dilutions & $\begin{array}{l}\text { No. of } \\
\text { L.L.** }\end{array}$ & Infectivity & Aging (hr) & $\begin{array}{l}\text { No. of } \\
\text { L.L. }\end{array}$ & Infectivity \\
\hline $\begin{array}{l}\text { Untreated } \\
\text { infectious } \\
\text { sap*. }\end{array}$ & 75 & 100 & $\begin{array}{c}\text { Untreated } \\
\text { infectious } \\
\text { sap. }\end{array}$ & 75 & 100 & $\begin{array}{c}\text { Untreated } \\
\text { infectious } \\
\text { sap. }\end{array}$ & 75 & 100 \\
\hline 40 & 70 & 93.3 & $10^{-1}$ & 73 & 97.3 & 5 & 70 & 93.3 \\
\hline 42 & 60 & 80.0 & $10^{-2}$ & 62 & 82.6 & 10 & 50 & 66.6 \\
\hline 44 & 53 & 70.7 & $10^{-3}$ & 50 & 66.6 & 15 & 40 & 53.3 \\
\hline 46 & 47 & 62.6 & $10^{-4}$ & 30 & 40 & 20 & 35 & 46.6 \\
\hline 48 & 42 & 56 & $10^{-5}$ & 21 & 28 & 25 & 30 & 40 \\
\hline 50 & 35 & 46.6 & $10^{-6}$ & 5 & 6.6 & 30 & 20 & 26.6 \\
\hline 52 & 30 & 40 & $10^{-7}$ & 0 & 0 & 35 & 18 & 24 \\
\hline 54 & 25 & 33.3 & $10^{-8}$ & 0 & 0 & 40 & 12 & 16 \\
\hline 56 & 21 & 28 & $10^{-9}$ & 0 & 0 & 45 & 3 & 4 \\
\hline 58 & 18 & 24 & $10^{-10}$ & 0 & 0 & 50 & 0 & 0 \\
\hline 60 & 13 & 17.3 & & & & 55 & 0 & 0 \\
\hline 62 & 11 & 14.6 & & & & 60 & 0 & 0 \\
\hline 64 & 5 & 6.6 & & & & 65 & 0 & 0 \\
\hline 66 & 0 & 0 & & & & 70 & 0 & 0 \\
\hline 68 & 0 & 0 & & & & 75 & 0 & 0 \\
\hline 70 & 0 & 0 & & & & 80 & 0 & 0 \\
\hline 74 & 0 & 0 & & & & 85 & 0 & 0 \\
\hline
\end{tabular}

* Infectious sap untreated kept under lab temperature.

** No. of local lesion (L.L) per $100 \mu 1$ of infectious sap assayed or Ch. amaranticolor as indicator plants.

$* * * \%$ of infectivity was calculated from 5 replicates leaves. 


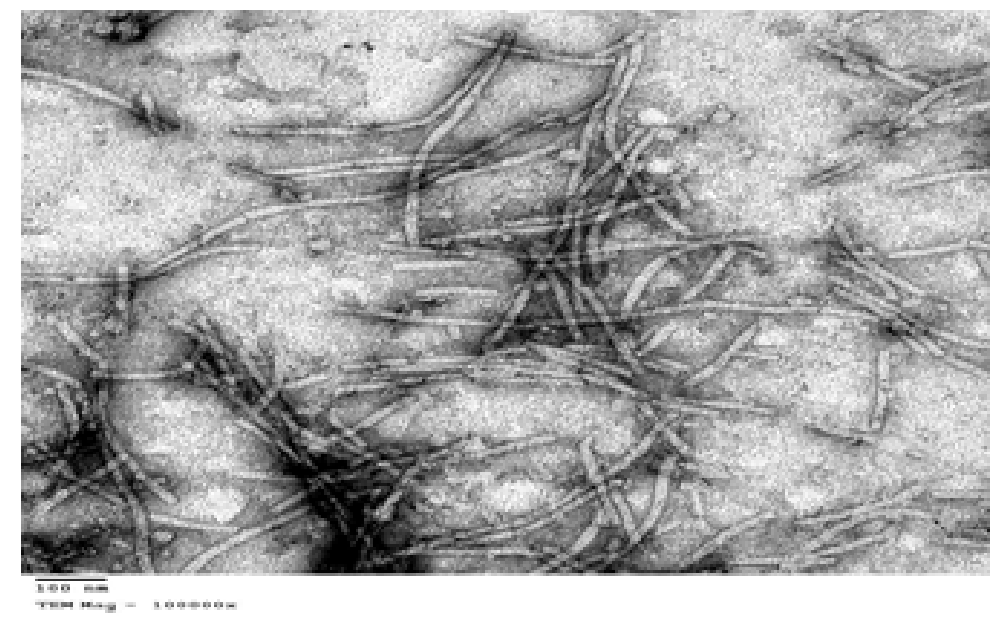

Fig. 4. Electron micrograph showing rod flexible particles (helical symmetry) of PVY isolate negatively stained with uranyl acetate with magnification power $100000 x$.

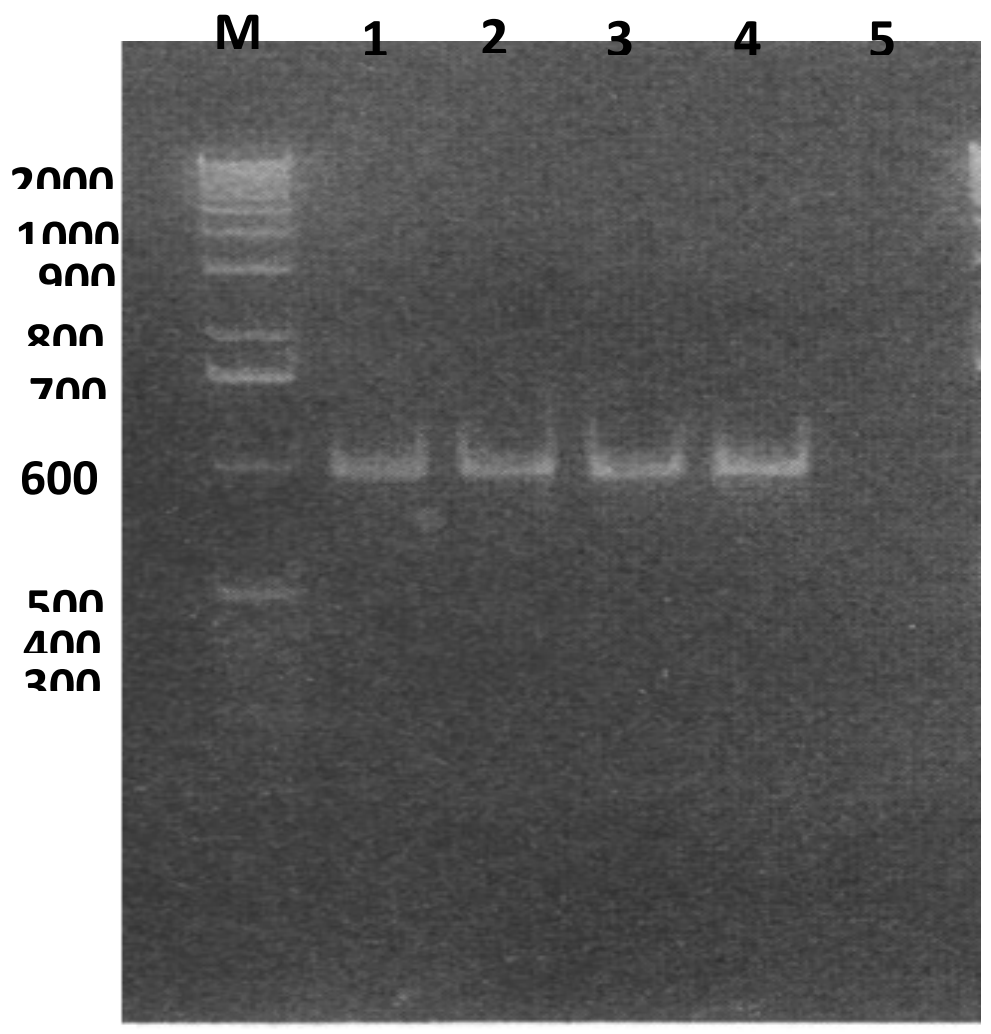

Fig. 5.Electrophoresis agarose gel (1.5\%) showing the integrity of total RNA extracted from mechanically infected potato leaves cv. spounta and DNA PCR-products of CP gene of PVY isolate using specific primers.

M: Marker RNA; 1: N. tabacum white burly; different locations; 5: Potato healthy.

2,3,4: Potato plants mechanically infected with PVY from 
The partial nucleotide sequence of the $\mathrm{CP}$ for PVY isolate was aligned with five isolates of PVY (Table 5). A phylogenetic tree of PVYCP revealed $99 \%$ degree of similarity to isolate PVY-2 and 97\% to PVY-3. The percentage of nucleotide sequence similarity of PVY-Egyptian isolate and PVY-4, PVY-5 and PVY-6 were 96, 95 and $94 \%$, respectively (Fig. 6).

Nucleotide sequence of $\mathrm{CP}$ gene translation:The partial nucleotide sequence of CP gene for PVY isolate was translated into 202 amino acids shown in (Fig. 7).

TABLE 5. Comparison between bases composition of partial nucleotide sequence of the cp gene of the studied pvy isolate with the corresponding sequence of other pvy isolates.

\begin{tabular}{|c|c|c|c|c|c|c|c|c|c|c|c|}
\hline \multirow{2}{*}{ Isolates } & \multicolumn{2}{|c|}{ MW KDa } & \multicolumn{2}{|c|}{$\mathbf{A}$} & \multicolumn{2}{|c|}{$\mathrm{C}$} & \multicolumn{2}{|c|}{ G } & \multicolumn{2}{|c|}{$\mathbf{T}$} & \multirow{2}{*}{ Similarity } \\
\hline & ssDNA & dsDNA & No & $\%$ & No & $\%$ & No & $\%$ & No & $\%$ & \\
\hline PVY-1 & 188.92 & 376.01 & 172 & 28.2 & 106 & 17.4 & 141 & 23.1 & 191 & 31.3 & \\
\hline PVY-2 & 606.53 & 1205.71 & 611 & 31.2 & 351 & 17.9 & 467 & 23.9 & 527 & 26.9 & $99 \%$ \\
\hline PVY-3 & 489.87 & 972.72 & 493 & 31.2 & 275 & 17.4 & 394 & 25 & 416 & 26.4 & $97 \%$ \\
\hline PVY-4 & 373.65 & 742.17 & 371 & 30.8 & 209 & 17.4 & 297 & 24.7 & 327 & 27.2 & $96 \%$ \\
\hline PVY-5 & 330.76 & 657.72 & 330 & 30.9 & 197 & 18.5 & 255 & 23.9 & 285 & 26.7 & $95 \%$ \\
\hline PVY-2 & 337.62 & 742.17 & 369 & 30.6 & 211 & 17.5 & 298 & 24.8 & 326 & 27.1 & $94 \%$ \\
\hline
\end{tabular}

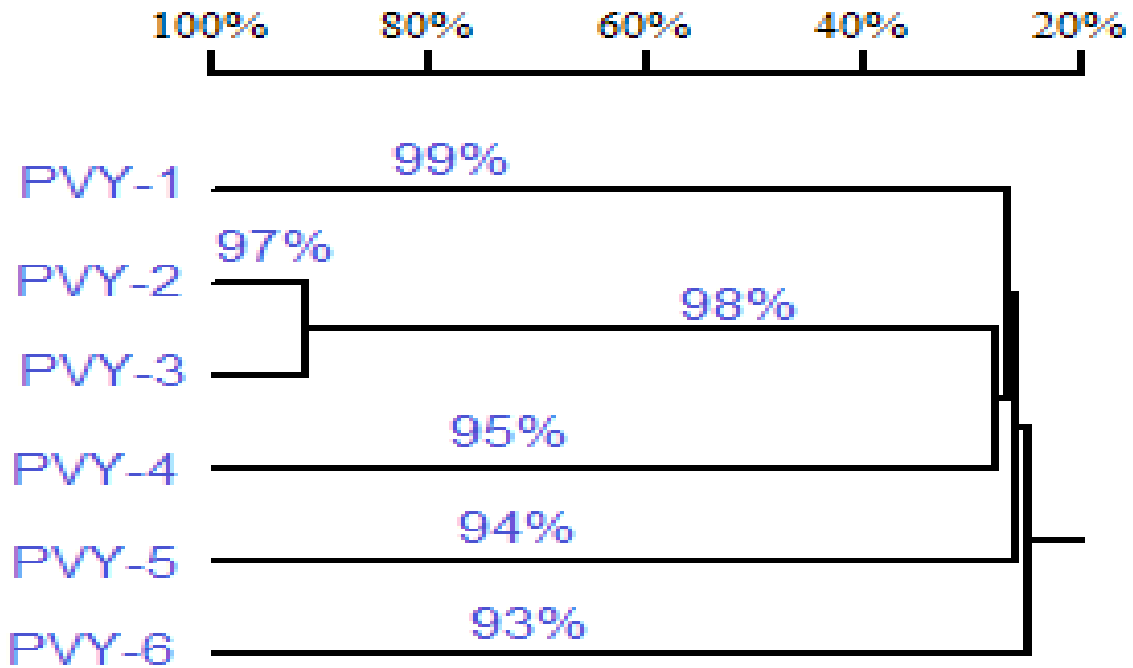

Fig. 6. Phylogenetic tree of PVY isolate based on the nucleotide sequences of the CP gene. The dendrogram displaying the percentage of sequence homology between the PVY/CP and the other five isolates of PVY.

Translation of PVY-EG_Coat_protein(1-202)

Universal code

Total amino acid number: 202 
1

1

61

20

121

40

181

60
10

30

40

50

60

CATATATGCCACGATATGGTTTAATTCGAAATCTGCGGGATATAAGTTTAGCGCGCTATG

$\begin{array}{lllllllllllllllllll}Y & M & P & R & Y & G & L & I & R & N & L & R & D & I & S & L & A & R & Y\end{array}$

\section{0}

80

90

100

110

120

CCTTTGACTTTTATGAAGTTACATCACGAACGCCAGTGAGGGCTAGGGAAGCGCACATAC

$\begin{array}{llllllllllllllllllll}A & F & D & F & Y & \text { B } & \text { V } & \text { T } & \text { S } & R & \text { T } & \text { P } & \text { V } & R & A & R & E & A & H & I\end{array}$

Fig. 7.Translation of partial nucleotide sequence of CP gene for an Egyptian PVY isolate produced 202 amino acids.

\section{Discussion}

Visual inspection followed by DAS-ELISA screening indicated that the naturally infected potato plants cvs. spounta were heavily infected with PVY; PVX and PLRV separately and mixed infections with percentage $32 \%, 16 \%$ and $8 \%$, respectively. These results were in agreement with (Mahfouz et al., 2004 and Kandeel, 2014). Detection of PVY was essentially based on distinct potyvirus symptoms (top necrosis, vinal necrosis and severe mosaic on potato leaves) observation followed by DAS-ELISA. This agree with that obtained by Mahfouz (2003) and Nasr El-Din (2007).

The PVY was isolated biologically on Ch.amaranticolor and gave small chlorotic lesions without halo. The crude sap containing PVY particles was inoculated on $N$. tabacum $\mathrm{cv}$. white burly. The observed typical external symptoms were leaf crinkle, mottling severe mosaic and stunting meanwhile, Piche et al. (2004) reported that, 58 PVY field isolates transmitted to tobacco, 11 isolates produced a mild mosaic symptom and the remaining 47 field isolates induced varying degrees of leaf necrosis including venial necrosis, severe stunting and leaf death. An Indian $\mathrm{PVY}^{\circ}$ common strain isolated from field-grown potato plants was maintained in $N$. glutinosa in an insect-free green-house (Gawande et al., 2011). The inoculations with single strain of PVY in both potato and tobacco plants results in $100 \%$ infection, with every plant inoculated displaying typical symptoms of PVY with mixed infections of PVY strains the success rate of infection varied from $66.6 \%$ to $100 \%$ (Mallik et al., 2012). High DAS-ELISA readings indicated that high specificity between antibodies and isolated PVY, as well as high virus concentration in infected potato plants. DAS-ELISA has proved to be very efficient for detection and identification of many viruses as reported by Clark \& Adams (1977). Because of their sensitivity, specificity and speed, potato tubers $\mathrm{cv}$. spounta was gave DAS- ELISApositive reaction.

Our results were in accordance with that obtained by many authors (Cojocaru et al., 2009; Alexander et al., 2010; Gwande et al., 2011; Sabir, 2012; and Nerway \& Kassim, 2014). The isolated PVY was mechanically transmitted by rubbing and tuber grafting where the virus isolate was parenchyma virus and non-persistent virus. Also the phosphate buffer which releases the virus particles from pigments and organelles of infected plants leading to increasing the virus particles. Mechanical transmission was considered as simple method for transmission of PVY instead of insect transmission. These results were in agreement with Gawande et al. (2011), Sabir (2012) and Nerway \& Kassim (2014).

PVY isolate infected some of tested plants of families, Solanaceae, Chenopodiaceae, Fabaceae, Cucurbitaceae, Compositae and Amaranthaceae. The results agreed with Mahfouz, (2003) and Nasr El-Din (2007). PVY isolate showed variation in symptoms and latent period on different tested hosts. The development of the new susceptible 
species and the new symptoms to PVY were due to the variation in environmental conditions and the production of new Potyvirus $Y$ strains as result of high rate of recombination between species or strains as well as within and a cross genera. PVY purification depends on separation of virus particles from plant constituents. Generally, use of n-butanol in clarification process helps to remove all cell membranes which contain lipid and lipoprotein and their precipitation at lowspeed centrifugation with less virus loss. Also, in final purification step including precipitation and differential centrifugation helps to precipitate the virus particles at high-speed centrifugation. The UV-spectrum of the purified virus gave maximal absorption (0.572) at $260 \mathrm{~nm}$, while the absorbency at $280 \mathrm{~nm}$ was 0.375 . The nucleic acid and protein gave the maximal absorption at 260 and $280 \mathrm{~nm}$, respectively. So, this result indicated a good and successful virus purifying caption. The purity of PVY solution was indicated by the value of A260/ A280 ratio which was 1.6. This result showed that the used procedures were successful for separating and purifying PVY from infected potato plant tissues. These results in the range of those obtained by Nerway \& Kassim (2014). Dijkstra \& de Jager (1998) stated that the value of A260/A280 ratio of elongated viruses is around 1.2 and for those with isometric particles around 1.7. The results showed that the PVY concentration in potato tissues was $1.25 \mathrm{mg}$ virus for each 100 gram of fresh plant tissue. This concentration was calculated by dividing the absorbency at $260 \mathrm{~nm}$ (A260) to Extinction coefficient of PVY (2.86). This result indicated the presence of high concentration of the virus particles in diseased plant tissues. TEM revealed the presence of flexible helical symmetry particles with diameter 11 X $570 \mathrm{~nm}$ when negatively stained with $2 \%$ uranyl acetate $\mathrm{pH}$ 7.0. These results were also previously reported by Nerway \& Kassim (2014). The spectrometrical tests indicated the good purification of the virus using differential centrifugation of the virus using differential centrifugation, precipitation and filtration techniques. In this concern, the purity of PVY was $0.483 \mathrm{mg}$ per gram of fresh plant tissue was stated by Nerway \& Kassim (2014). While, Sharma et al. (2013) reported that, electron microscopy of PVY revealed flexuous filamentous virus particles of $15 \times 750 \mathrm{~nm}$.

The detection of inclusion bodies can provide a rapid method for determining the presence of viral infection. The same result was reported by Amer (1999). From the obtained results of biological studies, it is reasonable to conclude that the isolated PVY from open fields in Egypt have some different characters from the other potyvirus strains. Current study indicated that PVY isolate have TIP $\left(66^{\circ} \mathrm{C}\right)$ which were differed with Mahfouz (2003) who reported that PVY have TIP 60, 64 and $66^{\circ} \mathrm{C}$ of PVY-C, PVY-A and PVY-B, respectively and agreed with Nasr El-Din (2007). Also, DEP was $\left(10^{-6}\right)$ which agreed with Nasr El- Din, (2007). Meanwhile, LIV was $45 \mathrm{~h}$ which disagreed with Mahfouz (2003) who found that PVY have DEP of $10^{-3}$ and was completely inactivated after $36 \mathrm{~h}$ at room temperature $\left(25\right.$ to $\left.28^{\circ} \mathrm{C}\right)$, however, agreed with Nasr El-Din (2007). The virus stability (TIP, DEP and LIV) as measured by infectivity (often in crude extracts) was an important criterion in attempting to establish group of viruses, control virus distribution and elimination of viruses both in vitro and open fields reported by Matthews (1992). The concentration of total RNA extracted from inoculated potato with PVY isolate was 3.2 per 0.5 gm leaves depending on the methods of extraction using guanidine-HCL, sodium phosphate, TrisHCL and ethanol. The isolated RNA was evaluated before PCR amplification using spectrophotometer at $260 \mathrm{~nm}$ which 0.572 running on agarose (1.5\%). The total RNA extracted from potato leaves cv. spounta indicating success of total RNA extraction with the high density.

PCR could be used in the diagnosis, detection and identification of viral disease as well as, detection of DNA or RNA pathogens in small samples (Singh \& Singh, 1996). The potyvirus genome consists of a positive sense ssRNA molecule of approximately $10 \mathrm{~kb}$ which is polyadenylated at $3^{`}$ end and is translated as single polypeptide encapsidated with one capsid protein (38 KDa).

The coat protein gene of potyviruses is located upstream of the 3' untranslated region and poly (A) tail. The CP gene is the most characterized gene in potyviruses. It is divided into three domains: the amino terminus, the core region, and the carboxy terminus. Both the amino and carboxy termini are variable, however the core region are conserved part in all potyviruses (Urcuqui et al. 2001). Therefore, for successful amplification process, specific DNA primers annealed to core region of coat protein genome was used in the polymerase chain reaction (PCR) as it is the most sensitive and reliable technique until now. So preparation of viral RNA is still a fundamental step in reverse transcription-PCR (RT-PCR) technique especially 
when applied in large scale testing as reported by Faggiolli et al. (1998).

The cDNAs were amplified by PCR using the oligonucleotides downstream and upstream primers for PVY- coat protein gene (PVY-CP). The genome of PVY contains partially overlapping open reading frames (OREs) bi-directionally arranged into two transcriptional units that are separated by an intergenic region. Such results indicate that PCR technique as an effective detection tool and greatly facilitate studies of potyvirus epidemiology and etiology. The RTPCR is an extremely sensitive and specific technique for the detection and determination of genetic diversity. The, size of the PCR products of coat protein gene (CP) amplified from both naturally and artificially infected potato plants was $610 \mathrm{bp}$ of spounta. These results were in agreement with Mahfouz (2003).

Recently, a combination of RT-PCR assays utilizing sequences within the 5'-untranslated region. P1 gene, and known recombination junction sites of the PVY genome has led to the separation of isolates recovered from Europe from those isolated in North America (Piche et al., 2004). A single amino acid substitution within the capsid protein produces a variant PVY strain known as $\mathrm{PVY}^{\mathrm{o}}-\mathrm{O} 5$. This variant does not induce vein necrosis in tobacco or tuber necrosis in susceptible varieties of potato. Furthermore, it is identified by RT-PCR based diagnostics at $\mathrm{PVY}^{\circ}$ and it has a typical $\mathrm{PVY}^{\circ}$ genome sequence (Alexander et al., 2010). ElAbsawy et al. (2012) collected different potato plants from an experimental station in Giza Governorate, Egypt, and these plants were tested using RT-PCR. PVY was amplified using primers represented portion of the coat protein $(\mathrm{CP})$ gene and 3'untranslated regions (UTR). Phylogenetic tree showed two main strain groups: Group I, regroups $\mathrm{PVY} \mathrm{N}^{\mathrm{N}}$ and $\mathrm{PVY} \mathrm{N}^{\mathrm{NTN}}$ strains, while group II includes $\mathrm{PVY}^{\mathrm{o}}, \mathrm{PVY}^{\mathrm{w}}$ and $\mathrm{PVY} \mathrm{N}^{\mathrm{N}: 0}$ strains.

TheEgyptianPVY isolate was clearly classified within group I and was more closely related to PVY ${ }^{\text {NTN }}$ strains. Ten nucleotide substitutions resulted in 3 conserved amino acid substitutions resulted in 3 conserved amino acid substitutions $\left(V_{1}{ }^{\circledR}, G_{7}{ }^{\circledR} \mathrm{E}, \mathrm{M}\right.$ or $\mathrm{V}$ and $\left.\mathrm{S}_{8}{ }^{\circledR} \mathrm{G}\right)$ and were able to differentiate between both groups. The partial coat protein region was more diverse than that of the 3'UTR (92.6-100\% and 97.7-100\% identity, respectively). The 3'UTR of the Egyptian isolate showed RNA secondary structures different from those of the 5 PVY strains. Sharma et al. (2013) studied the characterization of PVY on the basis of biological, serological and partial nucleotide sequence properties from different locations of Rajasthan.

A phylogenetic tree of PVY-CP revealed 99\% degree of similarity to isolate PVY-1, 98\% similarity to PVY-2, 97\% similarity to PVY-3. The percentage of nucleotide sequence similarity of PVY-Egyptian isolate and PVY-4, PVY-5 and PVY-6 were 95, 94, and 93\%, respectively.

\section{$\underline{\text { References }}$}

Ahmad, A.Y. (2005) Studies on some viral diseases infecting potatoes. M.Sc. Thesis, Faculty of Agriculture, Ain Shams University, 120 pp.

Alexander, V., Olga, K. and Nikolaeva, V. (2010) Serological properties of ordinary and necrotic isolates of Potato virusY: a case study of PVYN Misidentification. American Journal of Potato Research, 87, 1-9.

Al-Nagar, A.M. (2007) Studies on some plant virus diseases of some vegetable crops. M.Sc. Thesis, Faculty of Agriculture, Al-Azhar University, 165 pp.

Alyokhin, A., Sewell, G. and Groden, E. (2002) Aphid abundance and Potato virus $\mathrm{Y}$ transmission in imidacloprid-treated potatoes. American Journal of Potato Research, 79, 255-262.

Amer, A.A. (1999) Comparative studies on the diagnostic methods for Potato virus $\mathrm{Y}$ disease. M.Sc. Thesis, Department of Plant Pathology, Faculty of Agriculture, Ain Shams University, Cairo, Egypt, 153 pp.

Clark, M.F. and Adams, A.N. (1977) Characteristics of the microplate method for enzyme linked immunosorbent assay for the detection of plant viruses. Journal of General Virology, 34, 475-783.

Cojocaru, N., Carmen, L. and Mihaela, D. (2009) Potato virus Y. purification and achievement of antisera for identification of infected plants by ELISA. Analele I.C.P.C. Brasov, XX, 18-25.

Dijkstra, J. and de Jager,C.P. (1998) "Practical Plant Virology". Berlin; Heidelberg; New York: Springer. 459 pp.

El-Absawy, E.A., Mahmoud, Amal, Hemeida, A.A. and Helmy, M. (2012) Molecular variation of Potato virus Y Isolated from Egypt. International Journal of Virology, 8, 81-89.

Eraky, A., Abdel-Salam, S., Fahmy, F. G. and AbdelHaq, O (2014) Molecular identification of viruses responsible for severe symptoms on potato 
(Solanum sp) growing in Assiut Governorate (Upper Egypt). Journal of Biotechnology and Biomaterials, 3, 5.

Faggiolli, F., Pasquini, G. and Barba, M. (1998) Comparison of different methods of RNA isolation for Plum pox virus detection by reverse transcription, polymearase chain reaction, ActaVirologica, 42, 219-221.

Fauquet, C.M., Mayo, M.A., Maniloff, J., Desselberger, U. and Ball, L.A. (2005) Virus Taxonomy. Eighth Report of the International Committee on Taxonomy of Viruses. Elsevier Academic Press, San Diego, California, USA.

Gawande, S.J., Shukla, A., Chimote, V.P., Kaushal, N., Kaundal, P., Garg, I.D. and Chimote, K.P. (2011) Development of PCR-based techniques for the detection of immobilised Potato virus $\mathrm{Y}$ virions. Journal of Plant Pathology, 93(1), 127-132.

Hadidi, A., Montasser, M.S., Levy, L., Goth, R.W., Converse, R.H., Madkour, M.A. and Skrzeckowski (1993) Detection of Potato leaf roll and Strawberry mild yellow edge luteoviruses by reverse transcription polymerase chain reaction. Plant Disease, 77, 595-601.

Hossain, M. and Ali, M.S. (1992) Effect of Potato virus $\mathrm{Y}$ severities on virus concentration, dilution end point and potato yield. Bangladesh Journal of Plant Pathology, 8, 27-29.

Jordan, B.M. and Baker, J.R. (1955) A simple pyronin methyl green technique. Quari. S. Microscope. Sci. 96,177.

Kandeel, A.A. (2014) Molecular studies on production of potato minitubers virus-free. Ph.D. Thesis. Faculty of Science, Benha University., Egypt, 147 pp.

Mahfouz, S. (2003) Diagnosis of some plant viruses using modern techniques. M.Sc. Thesis, Faculty of Agriculture, Ain Shams University, 190 pp.

Mahfouz, S.A. Allam, E.K., Afifi, A.M. and ElDougdoug, Kh.A. (2004) Isolation of different isolates of PVX, PVY and PVS from naturally infected potato plants. The Ninth Conference of Agriculture Development Researches, 22-24 March, Cairo, Egypt.

Mallik, I., Nolan, R., Anderson, Niel, C. and Gudmestad (2012) Detection and differentiation of Potato virus $\mathrm{Y}$ strains from potato using immunocapture multiplex RT-PCR. American Journal of Potato Research, 89, 184-191.

Matthews, R.E.F. (1992) "Fundamentals of Plant Virology", Academic Press, New York, London, pp.402.
Nasr El-Din, M.A. (2007) Biological and molecular studies on Potato virus Y (PVY) M.Sc. Thesis, Faculty of Science, Benha University, 200 pp.

Nerway, Z.A.A. and Kassim, N.A. (2014) Potato Virus $\mathrm{Y}$ (PVY) purification and antiserum preparation. Journal of Agriculture and Veterinary Science, 7(4), 9-12.

Noordam, D. (1973) "Identification of Plant VirusesMethods and Experiments". Centre for Agricultural Publishing and Documentation, Wageningen, the Netherlands. pp. 207.

Piche, L.M., Singh, R.P., Nie. X. and Gudmestad, N.C. (2004) Diversity among Potato Virus Y isolates obtained from potatoes grown in the united states. The American Phytopathologial Society, 94(12), $1368-1375$.

Rupar, M, Ravnikar, M., Tušek-Žnidarič, M., Kramberger, P., Glaisc, L. and Gutiérrez-Aguirre, I. (2013) Fast purification of the filamentous Potato Virus Y using monolithic chromatographic supports. Journal of Chromatography A, 1272, 33- 40.

Rykbost, K.A., Hane, D.C. and Hamm, P.B. (1999) Effects of seed borne Potato Virus Y on Russet Norkotah performance. American Journal of Potato Research, 76, 91-96.

Sabir, J.S.M. (2012) Identification of six Potato Virus $\mathrm{Y}$ isolates from Saudi Arabia. African Journal of Biotechnology, 11(41), 9709-9715.

Sharma, P., Sahu, A.K., Verma, R.K., Mishra, R. and Gaur, R.K. (2013) Biological and molecular characterization of Potato VirusY infecting potato (Solanum tuberosum) in India. Asian Journal of Biological Sciences, 6(5), 257-264.

Sheikh, M., Ashraf, M. and Mahmood, I. (2012) Biological and molecular detection of a virus infecting Wedelia trilobata (Linno) Hitchc (A Medicinal herb). Journal of Plant Pathology and Microbiology, 3(2), 1-4.

Shukla, D.D., Ward, C.W. and Brunt, A.A. (1994) "The Potyviridae". CAB. International, Wallingford, England, $516 \mathrm{pp} ; 102$.

Singh, M. and Singh, R.P. (1996) Nucleotide sequence and genome organization of a Canadian isolate of the common strain of Potato virus Y (PVYO). Canadian Journal of Plant Pathology, 18, 209-224.

Sudarsono, S.L.Z., Woloshuk, Z., Xiong, G.M. and Hillmann, E.A. (1993) Protein cistrons from sixPotato virus $\mathrm{Y}$ isolates infecting tobacco. Archives of Virology, 132, 161-170.

Urcuqui-Inchima, S. Haenni, A.L. and Bernardi, F. (2001) Potyvirus proteins; A wealth of functions. Virus Research, 74, 157-175. 
Visser, J.C., Bellstedt, D.U. and Pirie, M.D. (2012) The Recent Recombinant Evolution of a Major Crop Pathogen, Potato virus Y. PLoS ONE. 7, e50631.
Walkey, D.G.A. (1985) "Applied Plant Virology" Wiley-Interscience Publications, New York, USA, pp.93-102.

الصفات الفسيولوجية والمعدية لفيروس واى البطاطس العزلة المصرية

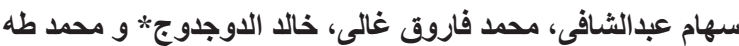

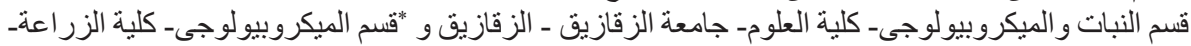
جامعة عين شمس- القاهرة- مصرول

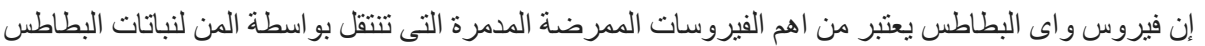
على مستوى العالم. عدوى فيروس واى البط البطاطس تسبب حو الفى 80\% انخفاض في انتاج البطاطس العالمى.

أن الهدف من هذه الدر اسة هو توصيف فيروس و ایى البطاطس (العزلة المصرية) المعدى لنباتات البطاطس

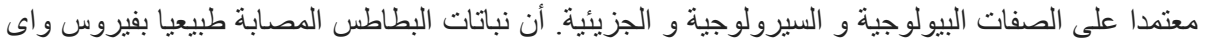

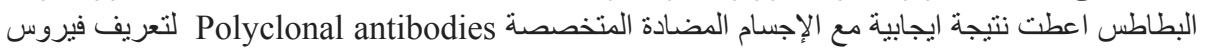

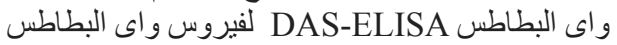

بحتفظ فيروس واى البطاطس بقدرته على احداث اصابة عند حفظه فى العصير الخام على درجة حرارة

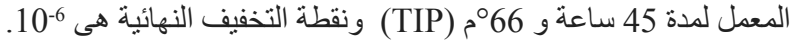

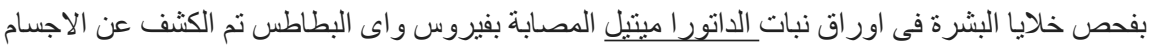

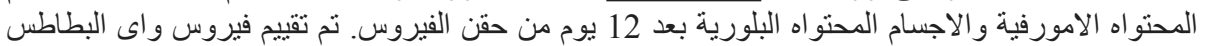

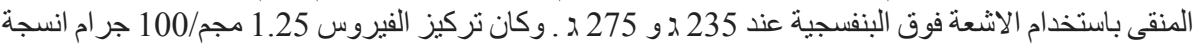

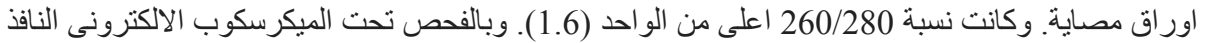

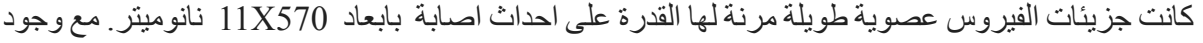
صفات و اضحة تتمثل فى 1024 :1 مقياس للاجسام المضادة.

تم تكبير cDNA باستخدام 1 PCR وباستخدام بادئ متخصص للغطاء البروتينى تم الحصول على 610 زوج من القو اعد النيتروجينية.

تطابق التتابع النيوكليتيدى اظهر ان عزلة فيروس واى البطاطس اوضحت نسبة تطابق 99\% -93 مع عزلات فيروسات واى البطاطس العالمية الأخرى.
} 